\section{Resistance of in Vitro-derived Cucumber Plants to Pythium aphanidermatum}

\author{
W. Msikita ${ }^{1}$ H.T. Wilkinson ${ }^{2}$ and R.M. Skirvin ${ }^{3}$ \\ University of Illinois, Urbana Champaign, IL 61801
}

Additional index words. in vitro, tissue culture, Cucumis sativus, disease resistance

\begin{abstract}
Embryonic axes-derived 'Burpless Hybrid' cucumber (Cucumis sativus L.) plantlets germinated on Murashige and Skoog (MS) medium supplemented with 16 combinations of BAP and NAA and seedlings derived from whole seeds cultured on semi-solid agar were inoculated in vitro with two isolates (WFU3 and WFM13) of Pythium aphanidermatum. All axes-derived plantlets and whole seedlings inoculated with WFM13 isolates were susceptible to blight and died 2 days after inoculation. Similarly, all seedlings inoculated with WFU3 isolates were killed within 2 days after inoculation; however, the rate of development and severity of blight varied among the axes-derived plantlets. Blight on axes-derived plantlets, regenerated on MS medium supplemented with $2 \mathrm{mg} \mathrm{BAP/liter}$ and $0.2 \mathrm{mg}$ NAA/liter, was significantly less than on regenerants cultured on all other amended MS media. On some media, callus developed on crowns and/or primary roots. The presence of callus influenced resistance to Pythium. In a second experiment, axes-derived cucumber regenerants from five genotypes, cultured on MS medium supplemented with $2 \mathrm{mg} \mathrm{BAP/liter}$ and $0.2 \mathrm{mg}$ N\&A/liter, were compared for their resistance to $P$. aphanidermatum isolate WFU3. Resistance was significantly greater for 'Burpless Hybrid' and 'Sweetslice' than for three other genotypes. Chemical names used: 6-benzylaminopurine (BAP); $\alpha$-naphthaleneacetic acid (NAA).
\end{abstract}

Damping-off and/or root rots are incited by various soilborne pathogens, including species of Pythium. These are ubiquitous in agricultural soils and have a broad host range that includes cucumbers (Bedlan, 1986; Hendrix and Campbell, 1973). Most pathogenic fungi derive nutritional energy from living cells and, to obtain these, they must penetrate or degrade the cell wall (Aist, 1976; Mount, 1978). Penetration of host cell walls is a complex process that has been examined for numerous pathogens (Murray and Maxwell, 1974) and appears to involve both mechanical and enzymatic means (Hendrix and Campbell, 1973; Murray and Maxwell, 1975) controlled by the pathogen. Structural and chemical constituents in the plant epidermal wall are postulated to influence penetration by pathogens. For example, cell maturation, rapid death, and suberization generally inhibit pathogenesis (Akai, 1959). Intracellular callose generally forms between the cell wall and plasma membrane at a location ad-

Received for publication 28 July 1989. This research was supported in part by the Univ. of Illinois Agricultural Experiment Station (Hatch 650323); the Illinois Turfgrass Assn., Chicago; the Mid-America Sod Growers Assn. of Illinois; and the joint Swedish International Development Authority (SIDA) and Zambian Ministry of Agriculture and Water Development (MAWD) project. The cost of publishing this paper was defrayed in part by the payment of page charges. Under postal regulations, this paper therefore must be hereby marked advertisement solely to indicate this fact. 'Graduate Student, Dept. of Horticulture.

${ }^{2}$ Associate Professor, Dept. of Plant Pathology and Agronomy.

${ }^{3}$ Professor, Dept. of Horticulture. jacent to the point of penetration. This material is an amorphous mass of polysaccharides and lignin. The epidermal cells usually intercept the pathogen first. The potential for a compatible interaction (i.e., disease) will be greatly affected by the physiological state of the host cell. Parenchymatus callose growing in a nutrient-rich environment represents a very different infection court than a structurally organized seedling. Hormonal amendments in callus culture media could affect the susceptibility to infection by pathogenic fungi. In addition, cell variation is BAP and NAA.

${ }^{2}$ Callus on primary roots and/or crown region. dead).

${ }^{x} \mathrm{n}=29$ or 30 . likely to occur during callus formation, which could result in a nonuniform infection court (Meinert and Delmer, 1977). In some tissue culture-derived cucumber plants, callus was observed to persist on the primary roots and/ or crown regions up to the time of transplanting to soil (Msikita, 1989). The persistence of this tissue on seedlings transplanted to soil could influence pathogenesis by $P$. aphanidermatum.

This study was undertaken to determine if the observed persistence of callus on some tissue culture-derived cucumber regenerants would affect pathogenesis by $P$. aphanidermatum.

Control seedlings. Thirty seeds of 'Burpless Hybrid' cucumber (Sakata Seed Co., San Francisco) were separated from their seedcoats, surface-sterilized in $10 \%$ bleach $(0.52 \%$ sodium hypochlorite, v/v), rinsed in sterile distilled water (SDW), and aseptically germinated in test tubes $(25 \times 150 \mathrm{~mm})$ containing $10 \mathrm{ml}$ of semi-solid agar [prepared by dissolving $8 \%$ (w/v) Difco-bacto agar in distilled water and autoclaving for $15 \mathrm{~min}$ at $\left.1.06 \mathrm{~kg} \cdot \mathrm{cm}^{-2}\right]$. After 3 weeks, seedlings with three to four leaves and tissue culture-derived plants were transplanted into plastic Conetainers (Ray Leach Conetainer Corp., Canby, Ore.) and inoculated with Pythium 2 days later.

Before transplanting, the Conetainers were thoroughly washed in $10 \%$ sodium hypochlorite solution $(0.52 \%, \mathrm{v} / \mathrm{v})$, rinsed two times with SDW, and dried in a bio-free environment. A nonsterile cotton ball was placed in the bottom of each Conetainer that was then filled with fine-textured vermiculite (which had been autoclave twice for $40 \mathrm{~min}$ at $1.06 \mathrm{~kg} \cdot \mathrm{cm}^{-2}$ on two separate days) to within $1 \mathrm{~cm}$ of the Conetainer's upper lip.

Tissue culture-derived plantlets. Forty-five seeds of 'Burpless Hybrid' cucumber were separated from their seedcoats and cut into pieces consisting of an embryonic axis and

Table 1. Ex vitro score distribution for Pythium aphanidermatum blight isolate WFU3 on 'Burpless Hybrid' cucumber embryonic axes germinated on Murashige and Skoog medium supplemented with

\begin{tabular}{|c|c|c|c|c|c|c|}
\hline \multirow{2}{*}{$\begin{array}{l}\text { BAP/NAA } \\
\left(\mathrm{mg} \cdot l \text { liter }^{-1}\right)\end{array}$} & \multicolumn{5}{|c|}{ Disease severity $^{y}$} & \multirow{2}{*}{$\begin{array}{c}\text { Callused } \\
\text { plants }(\%)\end{array}$} \\
\hline & 1 & 2 & 3 & 4 & $\overline{5}$ & \\
\hline \multicolumn{7}{|c|}{ No. of plants } \\
\hline $2.0 / 0.0$ & 0 & 2 & 0 & 10 & 18 & 55 \\
\hline $2.0 / 0.1$ & 0 & 0 & 0 & 0 & 30 & 0 \\
\hline $2.0 / 0.2$ & 12 & 8 & 5 & 0 & 4 & 76 \\
\hline $2.0 / 0.3$ & 4 & 0 & 0 & 6 & 24 & 33 \\
\hline $3.0 / 0.0$ & 0 & 0 & 0 & 0 & 30 & 0 \\
\hline $3.0 / 0.1$ & 0 & 0 & 0 & 0 & 29 & 0 \\
\hline $3.0 / 0.2$ & 0 & 0 & 0 & 0 & 30 & 0 \\
\hline $3.0 / 0.3$ & 0 & 0 & 0 & 0 & 30 & 0 \\
\hline $4.0 / 0.0$ & 0 & 0 & 0 & 0 & 30 & 0 \\
\hline $4.0 / 0.1$ & 0 & 0 & 0 & 6 & 24 & 33 \\
\hline $4.0 / 0.2$ & 1 & 0 & 2 & 4 & 23 & 57 \\
\hline $4.0 / 0.3$ & 0 & 1 & 1 & 5 & 22 & 45 \\
\hline $5.0 / 0.0$ & 0 & 0 & 0 & 0 & 30 & 0 \\
\hline $5.0 / 0.1$ & 0 & 0 & 0 & 0 & 30 & 0 \\
\hline $5.0 / 0.2$ & 0 & 0 & 0 & 0 & 30 & 0 \\
\hline $5.0 / 0.3$ & 0 & 0 & 0 & 0 & 30 & 0 \\
\hline
\end{tabular}

${ }^{y} 1=$ no blight on plants, $2=25 \%$ blight, $3=50 \%$ blight, $4=75 \%$ blight, $5=100 \%$ blight (plants 


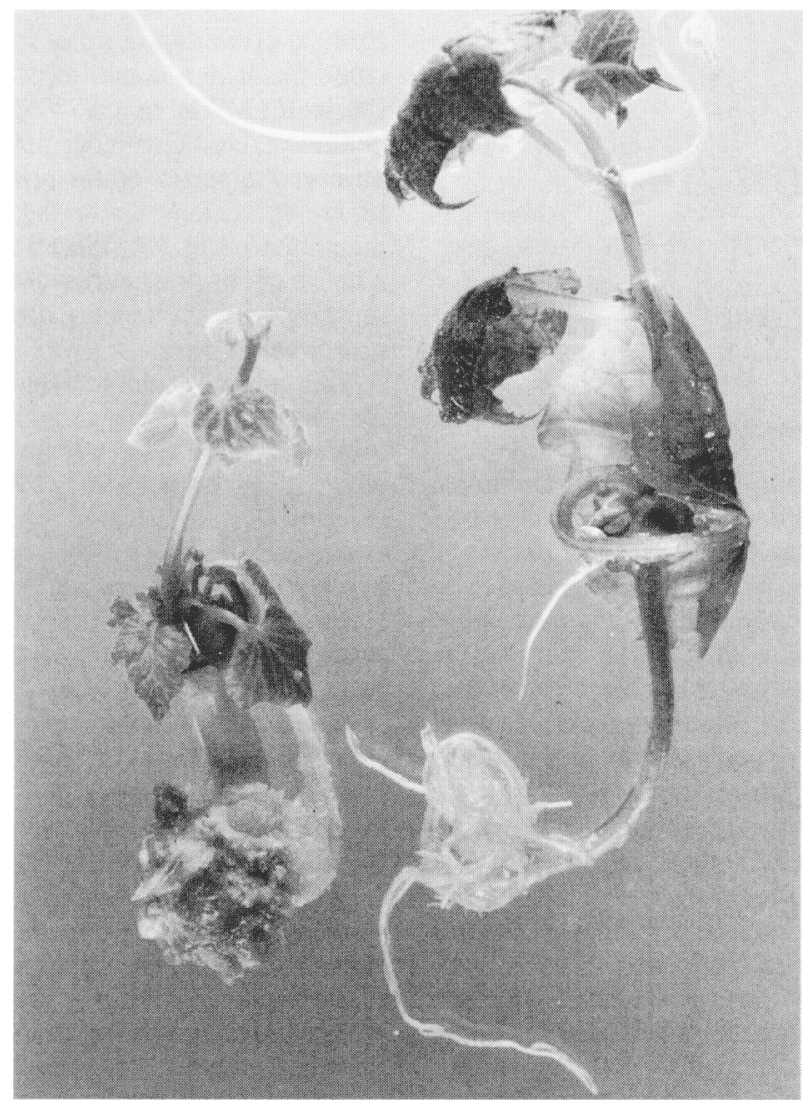

Fig. 1. Embryonic axes-derived seedlings that were germinated in vitro on Murashige and Skoog medium supplemented with (mg.liter ${ }^{-1}$ ) (left) 2 BAP and 0.2 NAA and (right) 3 BAP and 0.2 NAA. Note callus growth at the base of the plantlet on the left.

Table 2. Ex vitro mean scores of Pythium aphanidermatum (isolate WFU3) blight on embryonic axesderived cucumber cultivars and lines cultured on Murashige and Skoog medium supplemented with BAP $\left(2.0 \mathrm{mg} \cdot \mathrm{liter}^{-1}\right)$ and NAA $\left(0.2 \mathrm{mg} \cdot \mathrm{liter}^{-1}\right)(\mathrm{n}=15)$.

\begin{tabular}{lcc}
\hline \hline \multicolumn{1}{c}{ Cultivars/lines } & Disease severity & Seed source \\
\hline VGP 5058 & $4.5 \mathrm{a}$ & Asgrow \\
VGP 5049 & $5.0 \mathrm{a}$ & Asgrow \\
VGD 254 & $4.7 \mathrm{a}$ & Asgrow \\
Burpless Hybrid & $2.9 \mathrm{~b}$ & T. Sakata \\
Sweetslice & $2.8 \mathrm{~b}$ & Peto Seed \\
LSD $_{0.05}$ & 2.0 & \\
\hline \hline
\end{tabular}

${ }^{2} 1$ = no blight on plants, $2=25 \%$ blight, $3=50 \%$ blight, $4=75 \%$ blight, $5=100 \%$ blight (plants dead).

two cotyledons. To obtain some callused plantlets, a method-described by Msikita et al. (1990) was used. The axes were tied in a square of cheesecloth $(\approx 2 \times 2 \mathrm{~cm})$ and surface-sterilized (10 rein) in $10 \%$ commercial bleach to which $40 \mathrm{mg}$ Alconox powder had been added as a surfactant. The pieces were later rinsed five times (30 see/rinse) with SDW. The bags were untied and each piece was aseptically transferred to a culture tube $(25 \times 150 \mathrm{~mm})$ containing $10 \mathrm{ml}$ of modified Murashige and Skoog (MS) (1962) salt medium amended with 16 combinations of BAP and NAA (see Table 1). Before autoclaving (1.06 $\left.\mathrm{kg} \cdot \mathrm{cm}^{-2}, 15 \mathrm{~min}\right)$, Staba (1969) vitamins were added, the $\mathrm{pH}$ of the medium was adjusted to 5.7, and then Difcobacto agar $(7 \% \mathrm{w} / \mathrm{v})$ was added. Axes were placed on the media vertically, with the tipend positioned $\approx 1$ to $2 \mathrm{~mm}$ beneath the medium surface.

A second experiment was conducted using with 25 ppm rifampin Chemical Co, St. Louis) (PDA-R). Hyphal tips growing from the leaf tissue were indisterilized by immersing them in $10 \%$ bleach $\approx 1$ min and rinsing three times in SDV Small pieces $\left(\approx 5 \mathrm{~mm}^{2}\right)$ of surface-sterilized leaf were seeded into potato dextrose agar tum was isolated from infected Agrostis

embryonic axes from 'Burpless Hybrid', grow Seed $\mathrm{Co}$, on MS supplemented with $2 \mathrm{mg}$ BAP/lite tainers filled with vermiculite and incubated (30C, $16 \mathrm{hr}$ light for $48 \mathrm{hr}$ ) before inoculaion with $P$. aphanidermatum isolate WFU3. Fungal cultures. Pythium aphanidermaustris Huds collected from two locations in Champaign, Ill. Grass leaves were surface- vidually transferred to fresh PDA-R, cultured for 3 to 4 days on a laboratory bench, and transferred again to PDA. PDA was prepared as described by Langeran (1945). Rifampin was dissolved in methanol and filtersterilized (millipore filter $0.22 \mu \mathrm{m}$ ) before being added to sterilized PDA cooled to $45 \mathrm{C}$. Pythium cultured on water agar (17 g Difcobacto agar/liter water) was stored in sterile water on a laboratory bench for up to 6 months.

Pythium inoculum was produced by transferring mycelia from water agar onto PDA in a petri plate. The cultures were sealed with parafilm and incubated for $24 \mathrm{hr}$ in a growth chamber (30C, 90\% RH). Pythium had colonized the entire surface of PDA 24 $\mathrm{hr}$ after incubation, and then was cut into small culture blocks $\left(\approx 3 \mathrm{~mm}^{3}\right)$ using a sterile scapel. A single culture block was placed against the base of each cucumber seedling in Containers. Care was taken to ensure that the fungus was in direct contact with the plant surface. The inoculated plants were supported in a rack, and the whole assembly enclosed in a clear plastic bag and incubated in a growth chamber at $30 \mathrm{C}, 100 \% \mathrm{RH}$.

The first experiment consisted of $\approx 30$ seedlings (10 each inoculated with either Pythium isolate WFU3 or WFM13 or uninoculated) from each of the 16 media and seedlings germinated on agar.

The second experiment consisted of 15 seedlings from each of the five cultivars, all inoculated with WFU3. The experiments were repeated three times, and results were analyzed in a completely randomized design with each seedling as a replicate. Data were analyzed using the General Linear Model procedure of SAS (1982). Disease severity was assessed by using a severity rating of 1 to 5 ( $1=$ unaffected, $2=25 \%$ blight, $3=50 \%$ blight, $4=75 \%$ blight, and $5=100 \%$ blight).

Comparison of media. The growth of axesderived plantlets on the various media is described elsewhere (Msikita et al., 1990). More that $90 \%$ of the seedlings and plantlets inoculated with WFM13 were killed after 2 days and all were dead within 4 days. The plants appeared water-soaked and macerated and were damped-off at the soil surface.

Plants inoculated with WFU3 developed blight symptoms more slowly than those inoculated with WFM13. After 5 days, WFU3inoculated plants developed blight symptoms comparable to those observed 2 days after inoculation with WFM13. However, some tissue culture-derived plants with callus on their primary roots had lower disease severity when inoculated with WFU3 than with WFM13. Particularly notable were seedlings from medium supplemented with $2 \mathrm{mg}$ BAP/ liter and $0.2 \mathrm{mg}$ NAA/liter. On this medium, most plants formed callus on the primary roots and/or the crown and, therefore, had a lower disease-severity rating (2.1) than the rest (4.65.0 ).

Some plantlets developed callus on their crowns and/or primary root (Fig. 1). Some of these calli persisted ex vitro. More than $90 \%$ of the plants that had callus on their 
primary roots or crown had a lower disease severity when inoculated with WFU3 than with WFM13 (mean disease severity $=2.1$ ). The control plants were all susceptible (disease severity $=5$ ).

Disease severity distribution (three experiments) for isolate WFU3 on ex vitro seedlings varied for different growth regulator treatments. Plants from the treatment $2 \mathrm{mg}$ $\mathrm{BAP} /$ liter and $0.2 \mathrm{mg} \mathrm{NAA} /$ liter showed the lowest disease severity, as noted before, and had the highest proportion with callus (Table 1).

Comparison of genotypes. Cucumber genotypes differed in the rate and severity of disease development. Symptoms were similar on all genotypes, and 2 days after inoculation; all genotypes showed initial symptoms of blight. Overall mean disease severity was about equal on seedlings of VGP 5058, VGP 5049, and VGD 254 and significantly lower and about equal on 'Burpless Hybrid' and 'Sweetslice' (Table 2).

Cucumber seedlings germinated on agar and regenerants from various tissue culture media reacted differently ex vitro to the two $P$. aphanidermatum isolates. The isolate WFM13 was more aggressive, attacking all inoculated seedlings and regenerants within 2 days, while WFU3 did not infect plants from some of the treatments. Variation in disease severity between isolates of a single fungus has been reported for numerous other pathogens (Asian Vegetable Research Center, 1985; Ingram, 1987; White et al., 1987). Differences in disease severity among $P$. aphanidermatum isolates has been attributed to dissimilar production of toxin and pectolytic and cellulolytic enzymes (Sadik et al., 1983).

Plantlets cultured on different media reacted dissimilarly to WFU3. Plantlets with callus on their crowns and/or primary roots exhibited greater resistance to the pathogen (i.e., lower disease severity) than noncallused plants (Table 1). Pythium kills plant cells primarily by penetrating epidermal tissues, destroying membranes, and colonizing intracellularly (Winstead and McCombs, 1961). The observed resistance may be a consequence of the physical change in the morphology of callused cells. For example, callus formation is associated with signification of the outer cell walls (Hammerschmidt et al., 1984), and lignin is a resistant cell wall component. It is unlikely that the mass of callus simply slows fungal colonization, because pathogenic Pythium isolates are generally rapid colonizers, and, therefore, would have attacked both callus and plantlet.

Cucumber resistance to Pythium blight appears to be a genetically controlled reaction.
Genotypes differed in their resistance to the two Pythium isolates. Resistance can result from both active or passive defensive mechanisms. Formation of callus as an active defensive mechanism has been reported in several crop species (Allen and Friend, 1983; Bonhoff et al., 1987; Lazarovits et al., 1976).

Successful pathogenesis involves a complex interaction of factors involving the plant, pathogen, and environment. Inoculum density, temperature, and relative humidity must be favorable for successful pathogenesis to occur (Ogura, 1984). Differences in plant reaction to the two isolates of $P$. aphanidermatum could not have originated from these factors, as they were consistent in all experiments. In the second experiment, where several cucumber genotypes and one growth regulator combination was used, differences in disease severity could have resulted from differences in the genetic makeup of the plants.

This study shows that cucumber genotypes react differently to inoculation with Pythium isolates and that it is possible toalter the disease severity on cucumber regenerants from tissue culture using various growth regulator combinations. The presence of callus on tissue culture-derived regenerants increased resistance to infection by $P$. aphanidermatum ex vitro. The observed resistance may be a consequence of morphological changes in the outer cells of the pri-: mary roots and/or crowns or possibly of physiological mechanisms for resistance of the seedlings. This resistance could be overcome by more aggressive Pythium isolates, such as WFM13.

\section{Literature Cited}

Aist, J.R. 1976. Cytology of penetration-Fungi, p. 197-221. In: R. Heitefuss and P.H. Williams (eds.). Physiological plant pathology (Encyclopedia of plant physiology. New series. vol. 4). Springer-Verlag, New York.

Akai, S. 1959. Histology of defense in plants, p. 391-434. In: J.D. Horsfall and A.E. Diamond (eds.). Plant pathology. vol I. Academic, New York.

Allen, F.H. and J. Friend. 1983. Resistance of potato tubers to infection by Phytophthora infestans: A structural study of haustoria encasement. Physiol. Plant Pathol. 22:285-292.

Asian Vegetable Research Center. 1985. Host reaction to five Taiwan strains of turnip mosaic virus (TuMV). 1983: Progress report of the Asian Vegetable Research Center, Tainan. p. 113-117.

Bedlan, G. 1986. The most important fungal diseases of cucumbers. Pflanzenschutz 9:8-11.

Bonhoff, A., B. Rieth, J. Golecki, and H. Grisebath. 1987. Race cultivar-specific differences in callose deposition in soybean roots following infection with Phytophthora infestans: f. sp. glycinea. Planta 172:101-105.
Hammerschmidt, R., D.T.A. Lamport, and E.P Muldon. 1984. Cell wall hypdroxyproline enhancement and lignin deposition as an early event in the resistance of cucumber to Cladosporium cucumerinum. Physiol. Plant Pathol. 24:43-47.

Hendrix, F.F. and W.A. Campbell. 1973. Pythium as plant pathogens. Annu. Rev. Phytopathol. 11:77-98.

Ingram, D. M.. 1987. Influence of temperature and plant residues on pathology of Pythium spp. on wheat, barley, peas and lentils. Phytopathology 77:1239. (Abstr.)

Langeran, M. 1945. Precis de mycologic. Cronica Botanica. Waitham.

Lazarovits, G. and V.J. Higgins. 1976. Histological comparison of Cladosporium fulvum race 1 on immune, resistant, and susceptible tomato varieties. Can. J. Bet. 54:224-234.

Meinert, M.C. and P.D. Delmer. 1977. Changes in biochemical composition of the cell wall of cotton fiber during development. Plant Physiol. 59:1088-1097.

Mount, M.S. 1978. Tissue degradation, p. 279297. In: J.G. Horsfall and E.B. Cowling (eds.). Plant disease. vol. III. Academic, New York.

Msikita, W. 1989. In vitro regeneration and flowering of 'Burpless Hybrid' cucumber. MS Thesis, Univ. of Illinois, Urbana-Champaign,

Msikita, W., R.M. Skirvin, J.A. Juvik, W.E. Splittstoesser, and N. Ali. 1990. Regeneration and flowering in vitro of 'Burpless Hybrid' cucumber cultured from excised seed. HortScience 25:474-477.

Murashige, T. and F. Skoog. 1962. A revised medium for rapid growth and bioassays with tobacco tissue cultures. Physiol. Plant. 15:474497.

Murray, G.M. and D.P. Maxwell. 1974. Ultrastructure of conidium germination of Cochliobolus carbonum. Can. J. Bet. 52:2335-2340.

Murray, G.M. and D.P. Maxwell. 1975. Penetration of Zea mays by Helminthosporium carbonus. Can. J. Bet. 53:2878-2883.

Ogura, H. 1984. Germination of oospores of Pythium ultimum and aspect of disease occurrence caused by its oospores. Res. Rpt. Kochi Univ. Agr. Sci. 33:71-81.

Sadik, E. A., M.M. Payak, and S.L. Mehta. 1983. Some biochemical aspects of host-pathogen interactions in fithium stalk rot of maize. I. Role of toxin, pectolytic and cellulolytic enzymes in pathogenesis. Acts Phytopathol. Acad. Sci. Hungaricae 18:261-269. (English abstr.)

SAS Institute, Inc. 1982. SAS user's guide. SAS Inst., Inc., Cary, N.C.

Staba, J.E. 1969. Plant tissue culture as a technique for the phytochemist, p. 75-106. In: M.K. Seikel and V.C. Runeckles (eds.). Recent advances in photochemistry. vol. 2. AppletonCentury Crofts, New York.

White, D. G., J. Yanney, and B. Anderson. 1987. Variation in pathogenicity, virulence and aggressiveness of Colletotrichum graminicola on corn. Phytopathology 77:999-1001.

Winstead, N.N. and C.L. McCombs. 1961. Pectinolytic and cellulolytic enzyme production by Pythium aphanidermatum. Phytopathology 51:270-273. 